\title{
"The role of stokvels in South Africa: a case of economic transformation of a municipality"
}

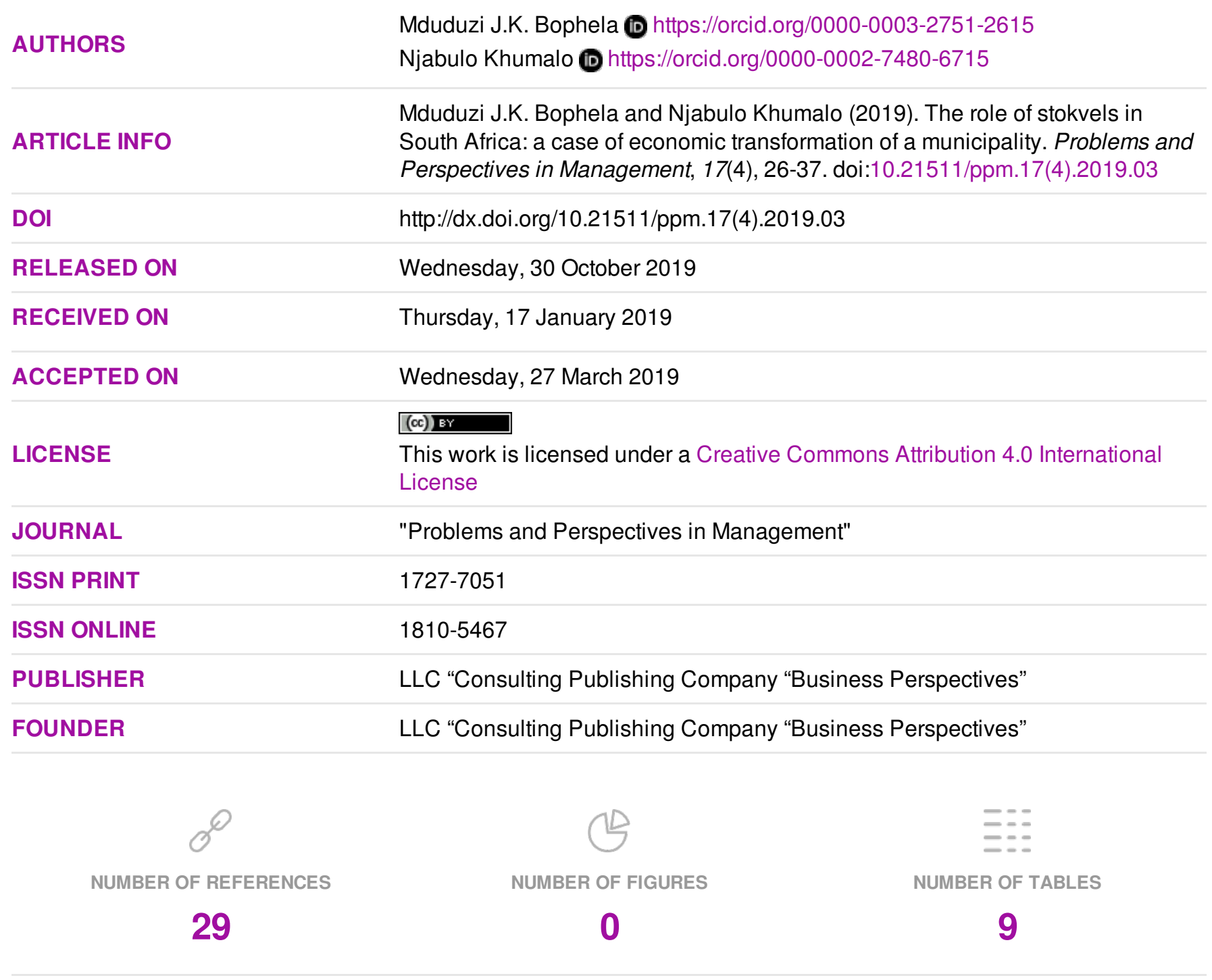

(c) The author(s) 2023. This publication is an open access article. 


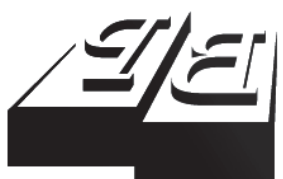

BUSINESS PERSPECTIVES

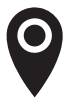

LLC "CPC "Business Perspectives" Hryhorii Skovoroda lane, 10, Sumy, 40022, Ukraine

www.businessperspectives.org

Received on: $17^{\text {th }}$ of January, 2019 Accepted on: $27^{\text {th }}$ of March, 2019

(C) Mduduzi J.K. Bophela, Njabulo Khumalo, 2019

Mduduzi J.K. Bophela, Ph.D. University of KwaZulu-Natal, South Africa.

Njabulo Khumalo, Ph.D., University of KwaZulu-Natal, South Africa.

\section{(c) (i)}

This is an Open Access article, distributed under the terms of the Creative Commons Attribution 4.0 International license, which permits unrestricted re-use, distribution, and reproduction in any medium, provided the original work is properly cited.

\section{THE ROLE OF STOKVELS IN SOUTH AFRICA: A CASE OF ECONOMIC TRANSFORMATION OF A MUNICIPALITY}

\begin{abstract}
Stokvel is a type of 'rotating savings and credit associations' found only in South Africa (SA) which have an estimated value of R49 billion and a membership of 11,5 million, in a country with a populace of 57 million and an informal economy with a total value of R160 billion - yet remain a hidden sector of the economy. This confirms that there is a shortage of the consulted literature on the model for integrating the stokvels into the economic policy framework of a municipality. Therefore, developing the stokvel industry could be key to poverty alleviation, reduction of unemployment and broadening equitable access to the ownership of the economy and capital accumulation; thus, improving the livelihoods and raising the standard of living. The objective of the paper is to determine the economic contribution factors of stokvels in the economic transformation of SA at a municipality level. The paper used a mixed methods design. A sample size of 395 stokvel groups' respondents for the quantitative research was selected using a simple random probability sampling method. The response rate was 100 percent. For the qualitative part, six policy-makers were interviewed using the purposive non-probability sampling method. The paper revealed that the money saving and investment, business opportunities and job creation, and policy development were the main economic contribution factors of stokvels in SA at the municipalities. The paper recommended for policy-makers to formulate an economic transformation policy framework inclusive of stokvels and to adopt their economic contribution factors.
\end{abstract}

\section{Keywords}

\section{JEL Classification}

stokvels, ROSCAs, economic transformation, informality, inclusive economy, policy framework

\section{INTRODUCTION}

There is absence (by omission or otherwise) of the role of stokvels, marginalization, and lack of recognition thereof in the official economic plans and policies of the government. Few studies have been conducted under the topic of stokvel in South Africa (SA). Researchers like Matuku and Kaseke (2014) argue that this absence could exacerbate the marginalization of stokvels to the periphery of the economy of SA. This translates to minimal economic policy support for this industry from the municipality level to the provincial and national government. While, Rakabe (2013) attributes that the marginalization of stokvels to the government's overemphasis on the oligopolistic mainstream economy as the main source of job creation, which tends to overlook the unexplored growth and employment potential of stokvels. The marginalization and exclusion of the role of stokvels are undesirable in the economic transformation of municipalities in SA, as they are a means of addressing the challenges of poverty, unemployment, and income insecurity. Therefore, this is the first study conducted to determine the role of stokvels in the economic transformation of municipalities 
in SA. Different types of stokvels such as savings stokvels, burial stokvels, investment stokvels, grocery stokvels, high-budget stokvels, birthday-party stokvels, and others can be found in SA but stokvels, in a broad sense, may be expected to both lead to and to follow from effective and efficient economic transformation (African Response Research, 2012). However, it is less clear how important specific types of stokvels are the means, agents, and catalysts for economic transformation in the municipalities across SA. A scientific approach to measure stokvels and to determine how their role influences positively or otherwise the economic transformation of municipalities is also not well covered in the scholarship body of literature. It is mostly black South Africans who often come together to form these ROSCAs in the South African municipalities, cities, townships, and villages (African Response Research, 2012; Matuku \& Kaseke, 2014). Therefore, the informal economy inclusive of stokvels has the potential to be the key driver of employment, and as such, it plays a major role in addressing the poverty, inequality, and inclusive growth (African Response Research, 2012). From the above mentioned scholars none, has focused on stokvel especial at the municipal level in SA. Therefore, the aim of the paper is to determine the role of stokvel in the economic transformation in the municipal environment in SA.

\section{LITERATURE REVIEW}

\subsection{Stokvels}

According to Matuku and Kaseke (2014), stokvels are an informal self-help union of people with a common goal of pooling the funds together on a weekly or monthly basis to address a common need due to poverty, unemployment, and income security. Arko-Achemfuor (2012, p. 129) points out that stokvels remain a section of the informal economy "through which millions of rands are transacted in the informal markets and are the biggest generator of informal funds in SA." Stokvels can provide a platform for periodic collective savings for members, whereby the total amount collected during a year is either reserved on behalf of the members or disbursed as a lump sum on an equal share (Neves \& du Toit, 2012). The literature revealed that the old practice of stokvels continues, on an upward trend, even in post-apartheid SA. Mostly black South Africans come together to form stokvels in the cities, townships, and villages (African Response Research, 2012; Mashingo \& Schoeman, 2012; Matuku \& Kaseke, 2014).

The research by African Response Research (2012) indicates that four provinces in SA dominate the stokvel landscape, namely: Gauteng (24\%), Limpopo (20\%), KwaZulu-Natal (14\%) and North West (11\%). Together these provinces account for $70 \%$ of all stokvel groups and $69 \%$ of all the stokvel population in SA. African Response Research (2012) further reveals that the urban/ rural split of stokvel groups within some provinc- es, for example, Gauteng, KwaZulu-Natal (KZN), are predominantly concentrated in urban areas. It is well documented by some scholars such as Arko-Achemfuor (2012), Roux (2012), Mashingo and Schoeman (2012), Fourie (2013), and experts in finance (Old Mutual, 2011) that the contributions from the stokvels run into billions of rands. The study by African Response Research (2012, p. 6) indicates that "there are eight (8) types of stokvel organizations in SA, with a membership of approximately 11,400,400 registered individuals, belonging to 811,830 stokvels; and collectively saving R44 billion a year." The most common eight (8) types of stokvels are: savings, burial, investment, grocery, high-budget, birthday-party, lobola (funds collected towards getting marriage) stokvels, and others (African Response Research, 2012; Matuku \& Kaseke, 2014).

\subsubsection{Economic contributing factors of stokvels}

Social and economic benefit for participating in stokvel activity is directed at a wide range of objectives, including: "generating income, bolstering food security, facilitating social connectedness, slowing the draw-down of a finite portfolio of assets" (Neves \& du Toit, 2012, p. 135). Vermaak (2000) cited in African Response Research (2012, p. 2) indicated that stokvel organizations enable their "members to have insurance against adversity such as death, equipping them with the financial support to fund various other functions agreed upon by the stokvel group as a collective, extending loans to needy members (inter alia for education, towards physiological needs such 
as housing, grocery shopping and business endeavors)". Several scholarly findings from ArkoAchemfuor (2012), Mashingo and Schoeman (2012), Matuku and Kaseke (2014), Hossein (2017) and reports from research organizations like African Response Research (2012) indicate the following reasons for and benefits of participating in ROSCAs like stokvels:

- ability to save, invest, and meet basic needs;

- $\quad$ sustaining the existence of formal businesses thus creating the employment;

- financing/starting of small businesses;

- women's empowerment;

- $\quad$ easy access to credit and mini-loans; and

- creation of social capital, moral support, and mutual assistance.

These benefits are economic factors aligned with the national development plan (NDP) adopted in 2013 as authored by the South African national planning commission, the SALGA (2012) blueprint guidelines for municipalities in adopting a more developmental approach towards an economy inclusive of informal economy and the IDP (2016/2017) for eThekwini Municipality. Meanwhile, most commentators' views are that stokvels are endowed with pro-social economic factors that are a good source for economic growth and development through job creation, savings and investment capabilities, extending of mini-loans and credit facilities, women empowerment and social capital (Josten, 2013; Li et al., 2015; Osakwe \& Ajayi, 2015; Chatterjee et al., 2017).

\subsubsection{Inclusive economy at local government}

A study by David et al. (2013) cites the eThekwini Municipality's “Durban's Informal Economy Policy" adopted in 2001 as pioneering and the successful implementation of its various elements. This policy was formulated for the economic inclusion of the informal economy in the eThekwini Municipality. In its current form, this policy excludes and marginalizes the stokvels industry in favor of street traders. The word 'stokvels' is men- tioned once under clause 7.2.12. The clause introduces stokvels as an innovative alternative solution for SMMEs to access financial support in eThekwini Municipality. According to David et al. (2013, p. 68), it has been suggested to the South African Local Government Association's (SALGA's) 278 member municipalities in SA that "a set of guidelines around the informal economy need to be incorporated into the IDP assessment process. This would include issues such as:

- presence of informal economy policy adopted and approved by the council;

- inclusion of the informal economy in the Local Economic Development (LED) plan;

- inclusion of the informal economy in infrastructure plans; and

- inclusion of the informal economy in the monitoring and evaluation process."

The SALGA's blueprint guidelines for municipalities towards an economy inclusive of informal economy and IDP (2012/2017) of the eThekwini Municipality are worthwhile considerations on how innovative ideas at municipality level can assist national government in developing the national policies to promote economic transformation. SALGA's (2012, p. 15) guidelines were "designed to assist municipalities in meeting their mandated requirements of achieving an integrated and developmental approach across all sectors." This paper has, however, noted that SALGA and invariably the eThekwini Municipality policies and plans exclude stokvels in the list of informal economy sectors. The exclusion of stokvel organizations further promotes their perpetual marginalization and lack of recognition as players in the informal economy.

\subsubsection{Economic transformation}

According to Lauridsen (2014, p. 429), "economic transformation alludes to processes of diversification, deepening and upgrading" of the structural economy. This definition by Lauridsen (2014) is aligned to Ulriksen's (2012) assertion that economic transformation in the global economy is driven primarily by the 
structural changes in the patterns of production, which bring about equity and broad-based transformation of the economy. Ulriksen (2012, p. 12) claimed that "broad-based social policies and economic transformation decrease poverty and inequality". Mpango (2013), cited in Wuyts and Kilama (2016), maintained that coupled with government policies aimed to review economic transformation for inclusivity and to promote a high savings culture as opposed to consumerism: a well-developed national plan will ensure that economic transformation will lead to enhanced growth and poverty reduction. The authors further indicate that one of the consequential and indicative outcomes of positive economic transformation of any economy is income inequality decline in the Gini coefficient (Ulriksen, 2012). The NDP (2013, p. 138) corroborates this when it claims that "economic transformation is about raising employment, reducing poverty and inequality, and raising standards of living and education including broadening ownership and control of capital accumulation." According to the OECD (2017) report, in 2015 SA had an inequality Gini coefficient of 0.62 , which decreased between 2008 and 2010, but has since stagnated. The "high Gini coefficient of SA illustrates the difficulty of reducing inequalities in a slowing economy" (Bhorat, Tseng, \& Stanwix, 2014, p. 225). The situation is exacerbated by the "continued low economic growth with rising population growth, thus posing a serious challenge for government finances" (OECD, 2017, p. 15). The view of a high Gini coefficient as an illustration of the slowing economy is also affirmed in a study by Ulriksen (2012) wherein the conclusions were drawn from comparing the economic transformation strategies of Mauritius and Botswana. The study indicated that "a consequence of the economic transformation was that income inequality declined during the 1980s in both economies from a Gini coefficient of 0.5 to about 0.37" (Ulriksen, 2012, p. 11).

Economic growth through economic transformation aims to bring about an inclusive economy for the majority of the impoverished communities in SA (SALGA, 2012; David, Ulrich, Zelezeck, \& Majoe, 2013). Different levels of government (national, local, municipal, and city council) have a growing recognition of the informal economy's ability to reduce poverty, unemployment, and meet the livelihood needs of communities. However, only a few of local governments and municipalities have thus far documented and "implemented specific policies aimed at creating an enabling environment for the informal economy so far" (David et al., 2013 , p. 4), while marginalizing stokvels to the periphery.

\section{METHODOLOGY}

The paper approached the research with a convergent parallel mixed methods technique in line with the pragmatic philosophical worldview (Creswell, 2014). Converging themes from the mixed method approach were established from participants using a methodological triangulation strategy. The research was located within the municipal boundaries of eThekwini in the province of KwaZulu-Natal (KZN) in SA. All the 197 towns/cities of the eThekwini Municipality were selected for data collection. EThekwini Municipality's gross domestic product (GDP) comprises $57.1 \%$ of KZN GDP and $9.1 \%$ nationally. The population of this research was all 36,333 stokvel groups in eThekwini Municipality. Since there are 811,830 stokvel groups in SA, of these, KZN stokvel groups constitute $14 \%$, which translates to 113,540 stokvel groups in KZN. The statistics of KZN and eThekwini Municipality was superimposed onto the stokvel groups. The scientifically extrapolated target population for the research yielded 36,333 stokvel groups found in eThekwini Municipality. Two sampling methods were employed for this paper: the simple random method of probability sampling on the larger population being the stokvel group's members, and purposive sampling method for the Municipality Council members (policy-makers) of eThekwini Municipality. For the quantitative research, a statistically accepted sample size of respondents from a population of 36,333 stokvel groups was mathematically calculated to be 395 .

A questionnaire instrument was constructed, and an interview schedule instrument was developed for data collection. The scales used in- 
cluded questions designed according to Likert scale as it is the easiest to understand (e.g., with responses: Strongly Agree-Agree-DisagreeStrongly Disagree) and questions that required the ranking in order of importance (e.g., with responses: Very High(VH)-High(H)-Medium(M)Low $(\mathrm{L})$-None $(\mathrm{N}))$. All the scales were then transcribed and coded by first normalizing the responses to all questions so that responses range from 1 to 2 (for questions with yes/no responses) or 1 to 4 (for questions with responses: Strongly Agree-Agree-Disagree-Strongly Disagree) or 1 to 5 (for questions with responses: Very $\operatorname{High}(\mathrm{VH})-\operatorname{High}(\mathrm{H})-\operatorname{Medium}(\mathrm{M})$-Low(L)None $(\mathrm{N}))$. During the in-depth interview sessions, the interview schedule was used as a guide, comprising the questions aligned with the aim, the research objectives and questions. All interviews were recorded on an audio-recorder. Observations during fieldwork were also noted and recorded. Data were collected, collated and thematically analyzed. Qualitative data were analyzed by transcribing the interview responses from participants and identifying the common themes using N-VIVO. The data were coded and classified accordingly. Quantitative data were analyzed using descriptive statistics and inferential statistics. The coded and transcribed data were entered into the Statistical Package for Social Sciences (SPSS).

\section{RESULTS}

Table 1. Response on affiliation of stokvels to NASASA

\begin{tabular}{l|c|c|c}
\hline \multicolumn{1}{c|}{ Response } & Frequency & Percent & $\begin{array}{c}\text { Cumulative } \\
\text { percent }\end{array}$ \\
\hline Yes & 76 & 19.6 & 19.6 \\
\hline No & 312 & 80.4 & 100.0 \\
\hline Total & 388 & 100.0 & - \\
\hline
\end{tabular}

The finding reveals a gap in policy-makers failing to enforce the exemption notices of the Bank Act 94 of 1990 granted to stokvels through National Stokvel Association of South Africa (NASASA) from National Treasury and the South African Reserve Bank. That a large majority $80.4 \%$ of stokvels are not registered members of NASASA should raise a concern to policy-makers in that it could mean that stokvels are operating outside of the exemptions of the Bank Act 94 of 1990 legal framework.

The findings show that, on average, each stokvel group member contributes R500.00 per month. Each stokvel group has, on average, fifteen members and with a population of 36,333 stokvels in eThekwini Municipality; the value per annum is R3,2 billion. There is a gap in policy-makers not recognizing the economic value of stokvels at such financial potency.

Table 2. Response on monthly contributions per stokvel member

\begin{tabular}{|c|c|c|c|c|}
\hline Monthly contribution & Frequency & Percent & Valid percent & Cumulative percent \\
\hline Between R100 and R250 & 118 & 30.4 & 30.4 & 30.4 \\
\hline Between R250 and R750 & 200 & 51.5 & 51.5 & 82.0 \\
\hline Between R750 and R1, 500 & 39 & 10.1 & 10.1 & 92.0 \\
\hline Between R1, 500 and R2, 500 & 26 & 6.7 & 6.7 & 98.7 \\
\hline More than R2, 500 & 5 & 1.3 & 1.3 & 100.0 \\
\hline Total & 388 & 100.0 & 100.0 & - \\
\hline
\end{tabular}

Table 3. Responses on municipality developing a policy framework

\begin{tabular}{|c|c|c|c|c|c|c|}
\hline Policy framework & Very High & High & Medium & Low & None & Terms \\
\hline \multirow{4}{*}{$\begin{array}{l}\text { Develop an economic policy framework inclusive } \\
\text { of stokvel industry }\end{array}$} & 152 & 135 & 65 & 18 & 18 & Frequency \\
\hline & 39.2 & 34.8 & 16.8 & 4.6 & 4.6 & Percent \\
\hline & 39.2 & 34.8 & 16.8 & 4.6 & 4.6 & Valid percent \\
\hline & 39.2 & 74.0 & 90.8 & 95.4 & 100.0 & Cumulative percent \\
\hline \multirow{4}{*}{$\begin{array}{l}\text { Invite all stakeholders of municipality to develop a } \\
\text { policy framework }\end{array}$} & 142 & 134 & 55 & 33 & 24 & Frequency \\
\hline & 36.6 & 34.5 & 14.2 & 8.5 & 6.2 & Percent \\
\hline & 36.6 & 34.5 & 14.2 & 8.5 & 6.2 & Valid percent \\
\hline & 36.6 & 71.1 & 85.3 & 93.8 & 100.0 & Cumulative percent \\
\hline
\end{tabular}


Table 4. Response on the municipality transforming the economy through stokvels

\begin{tabular}{|c|c|c|c|c|c|c|}
\hline Economy through stokvels & Very High & High & Medium & Low & None & Terms \\
\hline \multirow{4}{*}{ Present investment opportunities to stokvels } & 209 & 108 & 33 & 21 & 17 & Frequency \\
\hline & 53.9 & 27.8 & 8.5 & 5.4 & 4.4 & Percent \\
\hline & 53.9 & 27.8 & 8.5 & 5.4 & 4.4 & Valid percent \\
\hline & 53.9 & 81.7 & 90.2 & 95.6 & 100.0 & Cumulative percent \\
\hline \multirow{4}{*}{$\begin{array}{l}\text { Create a favorable environment for stokvels to co- } \\
\text { invest in the municipality projects }\end{array}$} & 150 & 103 & 55 & 38 & 42 & Frequency \\
\hline & 38.7 & 26.5 & 14.2 & 9.8 & 10.8 & Percent \\
\hline & 38.7 & 26.5 & 14.2 & 9.8 & 10.8 & Valid percent \\
\hline & 38.7 & 65.2 & 79.4 & 89.2 & 100.0 & Cumulative percent \\
\hline
\end{tabular}

Table 5. Response on types of stokvel groups

\begin{tabular}{|c|c|c|c|c|}
\hline Types of stokvel groups & Frequency & Percent & Valid percent & Cumulative percent \\
\hline Grocery stokvels & 262 & 67.5 & 67.5 & 67.5 \\
\hline Investment stokvels & 19 & 4.9 & 4.9 & 72.4 \\
\hline Savings stokvels & 84 & 21.6 & 21.6 & 94.1 \\
\hline High-budget stokvels & 1 & .3 & .3 & 94.3 \\
\hline Birthday stokvels & 8 & 2.1 & 2.1 & 96.4 \\
\hline Burial stokvels & 2 & .5 & .5 & 96.9 \\
\hline Other stokvels & 12 & 3.1 & 3.1 & 100.0 \\
\hline Total & 388 & 100.0 & 100.0 & - \\
\hline
\end{tabular}

This finding reveals a gap that there exists no economic transformation policy in eThekwini Municipality. The municipality needs to invite all stakeholders within the municipality to formulate an economic policy framework inclusive of stokvels.

This finding reveals a gap in that there is a need for policy-makers to develop a co-investment strategy that will mutually benefit the municipality and stokvels to promote investment opportunities to, and for, stokvels.

The findings reveal that the stokvel landscape in eThekwini Municipality is dominated by seven types of stokvels being grocery, savings, birthday, investments, high-budget and other. Burial type stokvels are no longer as common due to the incorporation of burial clauses in the agreements and mandates of most stokvels. The gap is that policy-makers see stokvels as one homogenous group, yet they require different strategic interventions from the municipality and government.

The finding show that the primary objective of stokvel groups is to save money. The finding indicates that policy-makers need to develop an economic policy framework that will promote savings and investments through stokvels.

Table 6. Response on primary objectives of stokvels

\begin{tabular}{l|c|c|c:c}
\hline \multicolumn{1}{c|}{ Primary objectives } & Frequency & Percent & Valid percent & Cumulative percent \\
\hline To socialize and network & 72 & 18.6 & 18.6 & 18.6 \\
\hline To save money & 240 & 61.9 & 61.9 & 80.4 \\
To create jobs by financing small business & 4 & 1.0 & 1.0 & 81.4 \\
To loan funds to members of your stokvel & 57 & 14.7 & 14.7 & 96.1 \\
To deposit our funds in high return investments & 15 & 3.9 & 3.9 & 100.0 \\
\hline Total & 388 & 100.0 & 100.0 & - \\
\hline
\end{tabular}

Table 7. Response on educational level of stokvel participants

\begin{tabular}{l|c|c|c|c}
\hline \multicolumn{1}{c}{ Educational level } & Frequency & Percent & Valid percent & Cumulative percent \\
\hline Matric & 150 & 38.7 & 38.7 & 38.7 \\
Diploma & 68 & 17.5 & 17.5 & 56.2 \\
Bachelor's degree & 35 & 9.0 & 9.0 & 65.2 \\
Masters/PhD & 13 & 3.4 & 3.4 & 68.6 \\
No schooling & 122 & 31.4 & 31.4 & 100.0 \\
Total & 388 & 100.0 & 100.0 & - \\
\hline
\end{tabular}


Table 8. Responses on how stokvels contribute to the economy

\begin{tabular}{|c|c|c|c|c|c|c|}
\hline Contribution to economy & Very High & High & Medium & Low & None & Terms \\
\hline \multirow{4}{*}{ Investing funds in big businesses } & 33 & 41 & 42 & 40 & 232 & Frequency \\
\hline & 8.5 & 10.6 & 10.8 & 10.3 & 59.8 & Percent \\
\hline & 8.5 & 10.6 & 10.8 & 10.3 & 59.8 & Valid percent \\
\hline & 8.5 & 19.1 & 29.9 & 40.2 & 100.0 & Cumulative percent \\
\hline \multirow{4}{*}{ Financing small businesses } & 48 & 54 & 60 & 49 & 177 & Frequency \\
\hline & 12.4 & 13.9 & 15.5 & 12.6 & 45.6 & Percent \\
\hline & 12.4 & 13.9 & 15.5 & 12.6 & 45.6 & Valid percent \\
\hline & 12.4 & 26.3 & 41.8 & 54.4 & 100.0 & Cumulative percent \\
\hline \multirow{4}{*}{ Advancing loans } & 98 & 100 & 66 & 30 & 94 & Frequency \\
\hline & 25.3 & 25.8 & 17.0 & 7.7 & 24.2 & Percent \\
\hline & 25.3 & 25.8 & 17.0 & 7.7 & 24.2 & Valid percent \\
\hline & 25.3 & 51.1 & 68.1 & 75.8 & 100.0 & Cumulative percent \\
\hline \multirow{4}{*}{ Savings opportunities for members } & 206 & 84 & 31 & 12 & 55 & Frequency \\
\hline & 53.1 & 21.6 & 8.0 & 3.1 & 14.2 & Percent \\
\hline & 53.1 & 21.6 & 8.0 & 3.1 & 14.2 & Valid percent \\
\hline & 53.1 & 74.7 & 82.7 & 85.8 & 100.0 & Cumulative percent \\
\hline
\end{tabular}

The findings reveal that participating in stokvel attracts people from all walks of life and is taken up by individuals across the educational level spectrum in eThekwini Municipality. In the absence of an economic transformation policy, there is a gap in that policy-makers have not identified stokvels as a platform to develop the society.

This finding is corroborated by finding from ArkoAchemfuor (2012) who concluded that in general stokvels in SA do not consider themselves as possible vehicles for financing or subsiding the SMMEs. The author further argued that the stokvel system is a potential source of start-ups working capital for its members and further recommended to policy-makers how they can use stokvels as one of the funding models for SMMEs in SA.

Table 9. Response on gender representation in stokvels

\begin{tabular}{l|c:c:c}
\hline Gender & Frequency & Percent & Cumulative percent \\
\hline Female & 320 & 82.5 & 82.5 \\
Male & 68 & 17.5 & 100.0 \\
\hline Total & 388 & 100.0 & - \\
\hline
\end{tabular}

The finding shows that stokvel groups are dominated by women at $82.5 \%$, whereas their male counterparts make up the balance.

\section{DISCUSSION}

\subsection{Money saving and investment}

Calvin and Coetzee (2010, p. 1) indicated that "there are stokvels that keep the reserves or savings to be used in special purpose investment vehicle to purchase an asset which is meant to generate income for the members," whereas Wiesław and Bartosz (2016, p. 123) posits that household savings "as an economic category, are very important in every country because they determine investments in the national economy, thereby influencing a country's further economic growth and development." The key finding for this paper is that the primary objective of $95.1 \%$ of stokvel groups is to save money, socialize and network and to loan funds to members. The research by African Response Research (2012) reveals that individuals participate in stokvels in order to take advantage of its ability to help save money. Khan, Khalid, and Shahnaz (2016, p. 171) also corroborate with the findings by arguing that "saving is vital to attain a higher level of investments, which in turn is a key driver of higher economic growth."

Findings of this paper reveal that $61.9 \%$ of the participants indicated 'saving money' as their stokvel's primary objective. This was further supported by a MC member who said: "stokvels are a best way of saving money," whereas another MC member said: "stokvels are seen as the platform for black to partake in the economy." This is corroborated by Matuku and Kaseke (2014, p. 509) who revealed that "membership in stokvels creates an opportunity to save. As a result, participants were able to engage in huge projects such as extending their houses. Another key benefit that participants derived from participating in stokvels was the opportunity to invest in household property." Arko-Achemfuor (2012) corroborates the findings with the view that due the exclusionary nature of the pre-1994 Apartheid system that discriminated 
against the black population forced a lot of blacks to join stokvels which acted as a critical source of saving.

Another key finding of this paper revealed that $61.5 \%$ of the stokvels' group members saved between R250 and R750 per month. According to measures of spread, $68.3 \%$ of stokvels' group members saved between R251 and R2,500 per month. This set of findings is corroborated by a finding from a research conducted by Old Mutual (2011) cited in Arko-Achemfuor (2012, p. 130) which indicated "that $38 \%$ of black South Africans are members of stokvels who on the average save R520 per month towards the pool fund of their stokvels." The findings show that the av- "c erage stokvel group contributes R500 per month. Further research revealed that the average size of a stokvel group in SA is 15 members. Research reports by Old Mutual (2011) and African Response Research (2012) corroborate this finding when indicating that the size of stokvel membership in SA ranges between 12 and 19. Arko-Archemfuor (2012) agrees with the finding of this paper by indicating a size range of between 7 and 14 members per stokvel group in SA.

According to the findings of this paper, the size of the stokvel industry in eThekwini Municipality is therefore valued at R3,2 billion. This finding is supported by MC members who said: "Stokvels in eThekwini Municipality pull together a total of R2 billion per annum." From this it can be extrapolated and generalized that the stokvel industry in SA is valued at R73,2 billion.

Some research reports and studies hold a negative view of the culture of saving money and lack of investments in SA as drivers of economic growth. One report is by ILO $(2016$, p. 8), which indicates that "SA's savings rates rank poorly compared with the rest of the world at $15.4 \%$ of GDP in 2015. Household debt as a percentage of household income now stands at 78.4\% (this includes loans, overdrafts, credit card debt, home loans, accounts)." Apergis, Simo-Kengne, and Gupta (2014, p. 83) corroborate ILO (2016) that "the low savings rate driven by high levels of consumer spending and the strong housing cycle over the last decades are two economic facts that spark new interest in the wealth effect in SA."
The major gap underlying the key findings is a need for the policy-makers to promote stokvels in the economic policy framework as a means to promote money saving and investments thereby influencing economic growth and development prospects.

\subsection{Business opportunities and job creation}

The findings in this paper reveal that $82.5 \%$ of stokvel group members are women. This finding is critical in creating business opportunities to empower women through stokvels. It is corroborated by Hossein $(2017$, p. 32) who concurs that "counting ROSCAs as part of the social economy allows us to pay attention to these women-led informal cooperatives in the Canadian context." This finding indicates that there is a gap in the policy-making since the absence of a municipal policy framework inclusive of stokvels is disempowering women and is discouraging the discourse of women emancipation in business. According to Eckhart-Queenan, Allen, and Behringer (2013, p. 33), "across the developing world, women own and operate an estimated eight to ten million SMEs." In percentage form that represents about $33 \%$ of all such businesses in the emerging markets. Eckhart-Queenam et al. (2013) go further to state that despite this, women continue to be under-represented and underserved as business owners by both banks and government policy-makers. Yet "the women-owned companies create much-needed jobs, raise people out of poverty, boost household income and contribute to overall economic prosperity" (Eckhart-Queenan et al., 2013 , p. 33). Baglaeva (2016, p. 8) maintains that "the economic empowerment of women is a matter for all. Inclusiveness does not only ensure a fairer world for both men and women, it also leads to faster and more sustainable economic growth."

The findings of this paper revealed that $70.1 \%$ of stokvel groups do not consider investing in big businesses as a contribution to the economy of eThekwini Municipality. Also, 58.2\% of stokvel groups do not consider financing small businesses as a contribution to the economy. This finding is supported by another finding in a study by Arko-Achemfuor (2012) which concluded that in general stokvels in SA do not 
consider themselves as possible vehicles for financing or subsiding the SMMEs. The author further argued that the stokvel system is a potential source of start-ups working capital for its members and further recommended to policy-makers how they can use stokvels as one of the funding models for SMMEs in SA. ArkoAchemfuor (2012, p. 131) posits that "it is important for developing countries to look for alternative sources of funding for SMMEs. The funds that are realized from stokvels, through intensive education of the general population, can help potential entrepreneurs to start and operate their businesses with some of the returns from this source." The Durban's Informal Economy Policy of 2001 refers to stokvels as an innovative alternative source of funding that the municipality should consider for purposes of raising finance for small businesses.

The paper discovered that stokvel groups have an arrangement with wholesalers wherein each has a single account at the wholesaler for all its group members. This finding is supported by the study of African Response Research (2012) where Massmart is cited as acknowledging the impact stokvels are making in the value chain of the "fast-moving consumable goods" (FMCG) sector of the economy in SA. Skinner (2006) cited in Neves and du Toit (2012, p. 140) postulates that the "informal sector in SA is tightly intertwined with formal sector value and commodity chains." Devey et al. (2006) cited in Neves and du Toit (2012, p. 140) has observed that the "linkages between the formal and informal sector include not only the leveraging of resources derived from the formal sector into informal enterprises but also an extensive interaction between formal and informal sector employment and an early acquisition of particularly favourable trading sites." MAKRO of Massmart has created a department with a full complement of staff members called 'Business Development - Emerging Markets' to cater for stokvels. This observation is corroborated by Ulriksen (2012) who states that one of the best ways out of poverty is through job creation. The rationale from MAKRO in establishing this department, as told by the Business Development Manager of the MAKRO, was: "we were tired of requests to exchange goods that had been handling more than once. Because stokvels would, for an example, buy each of their 15 members standard groceries which include '20kg of Aunty Caroline Rice.' Only to find that in their individual household members do not eat 'Aunty Caroline' but 'Tastic Rice or Basmati Rice.' The study by African Response Research (2012, p. 15) is in agreement with this finding in that "players in the FMCG sector already appreciate the value of stokvels with Massmart acknowledging the significant portion of sales associated with stokvels." Massmart acknowledges the need to look after the stokvel industry by "providing concessions such as bulk discounts, pro-active collection of orders and arranging affordable transport" for the ease of stokvels to move their goods around (African Response Research, 2012, p. 15).

Another observation confirmed by the Business Development Manager was that they are educating and empowering stokvels on how to handle their money. MAKRO wholesalers in the eThekwini Municipality are on a campaign to dissuade stokvel members from buying foodstuffs in bulk for storage at home since households are not designed to hold bulk food for periods of 6 to 12 months. After such lengthy periods, food items tend to go stale, spoil and lose their nutritional value. This facility allows stokvel members to make purchases and/or draw cash from their voucher cards/accounts at their convenience. The study by African Response Research (2012) agrees with the findings and further corroborates Arko-Achemfuor (2012) in that, there exists an opportunity for businesses (big and small) to partner with stokvels for Corporate Social Investment (CSI) or Enterprise Development.

This observation is proof that MAKRO across SA has created jobs and careers - this being an indirect spin-off from the stokvel industry. This corroborates the view that stokvels are a hidden industry and the official government statistics do no attribute the contribution of stokvels to the transformation of the South African economy. This is a clear indication that there is an unfulfilled gap by the municipality in developing a policy framework for creation of employment through stokvels. The identification of this gap in this study is corroborated by Doh $(2014$, p. 113$)$ 
who states that by their very nature "governments are primarily responsible for employment and they make every effort to create and manage a conducive environment for employment and unemployment reduction. Thus a high rate of unemployment is a sign of a not so well-functioning government." In corroborating with this observation Ulriksen $(2012$, p. 6) proposes in favor of this paper and the identified gap that, it "is for the state to consider whether the marginalized, unrecognized and underdeveloped sectors like stokvels become integrated parts of the economy rather than remain isolated from it."

\subsection{Policy development}

Stokvels are not only marginalized, misunderstood and unrecognized but are structurally disconnected from the core economy (Matuku \& Kaseke, 2014). The findings in this study revealed that $74 \%$ of participants held the view that it was of 'high to very-high importance' that eThekwini Municipality needed to develop a policy framework inclusive of the stokvel industry in order that the municipality could transform the economy through stokvels. This gap shows clearly that the MC of eThekwini Municipality need to revisit the Durban's Informal Economy Policy that was adopted in 2001. The gap identified by this paper is supported by a writer Mpango (2013) cited in Wuyts and Kilama (2016) who maintained that, coupled with government policies aimed to review economic transformation for inclusivity and to promote a high savings culture as opposed to consumerism, a well-developed national plan will ensure that economic transformation will lead to enhanced growth and poverty reduction.

The findings reveal that $80.4 \%$ of stokvels are not affiliated with NASASA. This reveals a gap of fear, mistrust and lack of knowledge about NASASA as mandated by National Treasury and the South African Reserve Bank. Yet NASASA was created to benefit and protection stokvels in terms of the exemption notices of the Bank Act 94 of 1990. Beyond policy formulation, an industry like stokvels with high levels of illiteracy needs regular interventions of training and development programs.

\section{CONCLUSION}

In spite of all the economic transformation plans by governments, poverty, unemployment and inequity still persist and the poor are forced to engage in self-help initiatives like stokvels to address these societal ills. Stokvels could therefore be a missing piece of a puzzle of how to advance economic transformation and thus increase employment opportunities without hampering economic growth. To reduce unemployment, alleviate poverty and inequality, stokvels need to become an integrated part of economic transformation strategy. The stokvel industry holds opportunities for growing the economy and absorbing the unemployed through the exploitation of existing and new markets. Furthermore, the industry is a ripe platform from which economy transformation could be accelerated through the empowerment and emancipation of women. It is for this reason that efforts to unlock these opportunities will require tailor-made and imaginative interventions by policy-makers on the one hand and, on the other hand, self-driven initiatives by the stokvels.

The economic benefits of participating in stokvels could form a basis for policy-makers in facilitating the training and development programs for stokvels. The ability of stokvels to mobilize savings and to channel small loans to small borrowers in an efficient and equitable way reduces uncertainty. It is recommended that municipalities in SA develop an economic transformation policy framework for an inclusive economy incorporating stokvels. The gaps identified in this paper necessitate policy-makers to revisit the IDP's and SALGA's 2012 blue-print of guidelines for municipalities to develop an approach towards an economy inclusive of informal economy. Policy development should include the mandate of NASASA and the exemption notices of the Bank Act 94 of 1990. These interventions should include municipalities and promote linkages between formal businesses (publicly listed on the stock exchange and private) and stokvels. 


\section{REFERENCES}

1. African Response Research (2012). Stokvels - A hidden economy (19 p.).

2. Apergis, N., Simo-Kengne, B. D., \& Gupta, R. (2014). The long-run relationship between consumption, house prices, and stock prices in South Africa: evidence from provincial-level data. Journal of Real Estate Literature, 22(1), 83-99. Retrieved from http://hdl.handle. net/2263/41342

3. Arko-Achemfuor, A. (2012). Financing Small, Medium and Micro-Enterprises (SMMEs) in Rural South Africa : An Exploratory Study of Stokvels in the Nailed Local Municipality, North West Province. Journal of Sociology Soc Anth, 3(2), 127-133. https://doi.org/10.1080/09766634. 2012.11885572

4. Baglaeva, E. (2016). Unlocking women's economic potential. Forum, 3, 8-9. Retrieved from http://www.intracen.org/article/ Unlocking-womens-economicpotential/

5. Bhorat, H., Tseng, D., \& Stanwix, B. (2014). Pro-poor growth and social protection in South Africa: Exploring the interactions. Development Southern Africa, 31(2), 219-240. https://doi.org/10. 1080/0376835X.2013.878242

6. Calvin, B., \& Coetzee, G. (2010). A Review of the South African Microfinance Sector 2009.

Retrieved from http://www.up.ac. $\mathrm{za} / \mathrm{media} /$ shared/Legacy/sitefiles/ file/1/3841/volumeiisectionivspecialproducts.pdf

7. Chatterjee, S., Fan, L., Jacobs, B., $\&$ Haas, R. (2017). Risk Tolerance and Goals-based Savings Behavior of Households: The Role of Financial Literacy. Journal of Personal Finance, 16, 66-77. Retrieved from https://papers.ssrn. $\mathrm{com} / \mathrm{sol} 3 /$ papers.cfm?abstract_ $\mathrm{id}=2918014$

8. David, S., Ulrich, O., Zelezeck, S., \& Majoe, N. (2013). Managing Informality: Local government practices and approaches towards the informal economy. Learning examples from five African countries. Retrieved from http:// www.enterprise-development. org/wp-content/uploads/managing_informality_local_governments_practices_towards_the_informal_economy.pdf

9. Doh, S. (2014). Social capital, economic development, and the quality of government: How interaction between social capital and economic development affects the quality of government. Public Administration, 92(1), 104-124. https://doi.org/10.1111/ padm.12041

10. Eckhart-Queenan, J., Allen, J., \& Behringer, C. (2013). Women Inc. Business Strategy Review, 4, 32-35.

11. eThekwini Municipality (2016). Integrated Development Plan 5 Year Plan: 2012-2017; 2016/2017 IDP Annual Review, Integrated Development Plan. Retrieved from www.durban.gov.za.

12. Fourie, F. (2013). Reducing unemployment: Waiting for high growth? Waiting for Godot? (7 p.). Retrieved from http://www. econ3x3.org/sites/default/files/ articles/Fourie March 2013 Unemployment-Waiting for growth or Godot FINAL.pdf

13. ILO (2016). Enabling Environment for Sustainable Enterprises in South Africa. Retrieved from http:// www.ilo.org/wcmsp5/groups/ public/---ed_emp/---emp_ent/--ifp_seed/documents/publication/ wcms_459981.pdf

14. Josten, S. D. (2013). Middle-class consensus, social capital and the fundamental causes of economic growth and development. Journal of Economic Development, 38(1), 1-26. Retrieved from https:// ideas.repec.org/a/jed/journl/ v38y2013ilp1-26.html

15. Khan, A. H., Khalid, U., \& Shahnaz, L. (2016). Determinants of Household Savings in Pakistan: Evidence from Micro Data. Journal of Business \& Economics, 8(2), 171-201.
16. Lauridsen, L. S. (2014). Governance and economic transformation in Taiwan: The role of politics. Development Policy Review, 32(4), 427-448. http://dx.doi.org/10.1111/ dpr.12062

17. Li, Y., Wang, X., Westlund, H., \& Liu, Y. (2015). Physical Capital, Human Capital, and Social Capital: The Changing Roles in China's Economic Growth. Growth and Change, 46(1), 133149. https://doi.org/10.1111/ grow. 12084

18. Mashingo, P., \& Schoeman, C. (2012). Stokvels as an instrument and channel to extend credit to poor households in South Africa. Journal of Economics, 5, 49-61. https://doi.org/10.4102/jef. v5i1.305

19. Matuku, S., \& Kaseke, E. (2014). The role of stokvels in improving people's lives: The case in orange farm, Johannesburg, South Africa. Social Work, 50(4), 504-515. Retrieved from http://www.scielo.org.za/scielo.php?script=sci_arttext\&pid $=$ S0037-80542014000400004

20. National Planning Commission South Africa (2013). National Development Plan. Our future - make it work. Retrieved from http://www.poa.gov.za/news/ Documents/NPCNationalDevelopmentPlanVision2030-lo-res.pdf.

21. Neves, D., \& du Toit, A. (2012). Money and Sociality in South Africa's Informal Economy. Africa, 82(1), 131-149. https://doi. org/10.1017/S0001972011000763

22. OECD (2017). OECD economic surveys: South Africa. OECD Publishing.

23. Old Mutual (2011). Special Feature: Stokvels/savings \& investment clubs. Retrieved from https://www.oldmutual.co.za/ docs/default-source/personalsolutions/financial-planning/ savings-and-monitor/latestresearch-results/researchresultsnov2011stokvel.pdf?sfvrsn=2 
24. Osakwe, C., \& Ajayi, J. O. C. (2015). Modelling Brand Performance of SME. Economic Computation and Economic Cybernetics Studies and Research, 4, 243-260

25. Roux, R. (2012). Old Mutual Savings and Investment Monitor July 2012: Savings A reminder of what we said before and what has happened the past 18 months? Retrieved from https://www.oldmutual.co.za/docs/default-source/ personal-solutions/financialplanning/savings-and-monitor/ latest-research-results/macroeconomicview.pdf?sfvrsn=2
26. SALGA (2012). Making the Informal Economy Visible: Guidelines for Municipalities in Respect of Adopting a More Developmental Approach Towards the Informal Economy. Retrieved from http://led.co.za/sites/default/files/cabinet/orgname-raw/ document/2012/municipal_informal_economy_guidelines_final_june2012_v2_0.pdf

27. Statistics South Africa (2017) Quaterly Labour Force Survey Quarter 1: 2017. Retrieved from http://www.statssa.gov.za/publications/P0211/P02111stQuarter2017.pdf
28. Ulriksen, M. S. (2012). Economic transformation affect poverty and inequality: Lessons for South Africa How social security policies and economic transformation affect poverty and inequality: Lessons for South Africa. Development Southern Africa, 29(1), 3-19.

29. Wiesław, D., \& Bartosz, Ś. (2016). An Allocation Analysis of Polish Household Savings Invested in Financial Assets, 2003-2014. Contemporary Economics, 123 136. https://doi.org/10.5709/ ce.1897-9254.204 